\title{
BIRUTE KLAAS-LANG 60
}

\author{
DOI: https://doi.org/10.12697/jeful.2017.8.1.01a
}

19. märtsil 2017 sai 60 -aastaseks Tartu Ülikooli eesti keele võõrkeelena professor Birute Klaas-Lang. Sünnipäevalaps tähistab sel aastal teistki tähtpäeva: aasta alguses täitus Birute Klaas-Langil Tartu Ülikooli tööle asumisest 30 aastat. Juubilari akadeemiline ja ühiskondlik tegevus on olnud viljakas: ta on tuntud ja tunnustatud keeleteadlane ning keele- ja hariduspoliitika ekspert.

Birute Klaas-Lang lõpetas 1975. aastal kuldmedaliga tollase Tartu 5. Keskkooli (Tamme Gümnaasium), misjärel jätkas õpinguid Tartu Riiklikus Ülikoolis eesti filoloogia erialal. Valitud eriala lõpetas ta cum laude 1981. aastal. Oma esimesel akadeemilisel töökohal TRÜ praktilise eesti keele kateedri vanemõpetajana alustas ta 1987. aastal.

Akadeemilise teekonna kestel on Birute nii töötanud arvukatel ametikohtadel alma mater' is ja välisülikoolides kui ka täitnud mitmeid ühiskondlikke kohustusi. Birute on töötanud vanemõpetaja ja dotsendina, kuulunud algusest peale 1989. aastal loodud eesti keele (võõrkeelena) osakonna töötajate hulka, juhtinud keelekeskuse tööd (19971999), olnud filosoofiateaduskonna dekaan (1999-2005) ning Tartu Ülikooli õppeprorektor (2006-2010). Birute Klaas-Lang on olnud Tartu Ülikooli senati liige, alates 2017. aastast on ta Tartu Ülikooli nõukogu liige. Akadeemiline teekond on Birute kahel korral viinud Helsingi ülikooli soome-ugri keelte ja kultuuride osakonda: esmalt külalislektoriks (1991-1995), hiljem sama osakonna külalisprofessoriks (2012-2016). Ka Helsingis õpetamise ajal on Birute jäänud seotuks Tartu Ülikooliga.

Erialaselt ning ühiskondlikult aktiivse professorina kuulub Birute Klaas-Lang paljudesse Eesti ja ka rahvusvahelistesse nõukogudesse, komisjonidesse, teadus-, arendus- ja koostöövõrgustikesse. Esile tõstmist väärib Birute Klaas-Langi aktiivne tegevus Eesti keelenõukogu pikaajalise liikme (alates 2001) ja esimehena (alates 2005). Viimase ametiga on kaasnenud ülesanne reageerida seisukohavõttudega päevakajalistele (keele)sündmustele, korraldada keelefoorumeid ja temaatilisi seminare ning esindada Eestit Euroopa riiklike keeleinstitutsioonide föderatsioonis (EFNIL). 
Viimased kümmekond aastat on Birute Klaas-Lang juhtinud eesti keele ja kultuuri akadeemilise välisõppe nõukogu tööd. Birute on palju panustanud eesti keele võõrkeelena uurimissuuna arendamisse ning käekäiku. Lisaks juhiülesannetele on Birute loomupärase energiaga meeleldi tegelenud praktiliste ülesannetega, olgu selleks siis konverentside sarja "Emakeel ja teised keeled" ning "Eesti keel ja kultuur maailmas" korraldamine või Soome-perioodidel Helsingi ülikooli tudengite igakevadised kultuurireisid Eestisse. Juubilar on oodatud esineja ja arvamusliider Leedu akadeemilistes ringkondades. 2003. aastast on ta Leedu Vabariigi aukonsul Tartus ja Tartumaal.

Birute Klaas-Langi peamised uurimisalad on keeletüpoloogia, väliseesti keel ning eesti keele teise keelena / võõrkeelena omandamine ja õpetamine. Keelestruktuuri teemadest on Birute Klaas-Langile huvi pakkunud eesti ja leedu süntaks, ennekõike subjekti, objekti ja predikatiivi küsimused. Võrdlevad, kontrastiivsed uuringud ongi Birute teadustöös olnud läbivaks teemaks ning ikka ja alati on tema huvi pälvinud just eesti ja leedu keele võrdlus. Oma diplomitöös (1981) käsitles Birute Klaas-Lang eesti ja leedu keele lihtlauseid ning paar aastat hiljem (1983) samal teemal avaldatud saksakeelne artikkel on ühtlasi tema esimene teadusartikkel. 1988. aastal kaitstud kandidaadiväitekirjas käsitles Birute Klaas-Lang eesti ja leedu keele struktuurilisi ühisjooni. Lisaks on Birute huvi pälvinud Balti keeleareaali atribuutkonstruktsioonid ja adressaatobjekt, sõnaalguline konsonantühend ning kohakäänded. Teadustöö hilisemal perioodil lisandusid mitmekeelsuse, Rootsi eestlaste keelekujude ning suhtluskäitumise teemad. Kolmel viimasel aastal on Birute Klaas-Lang aktiivselt tegelenud Eesti vene õppekeelega koolide riigikeele õppe korralduse ja probleemidega. Sel alal on Birute Klaas-Langi juhitud töörühmal valminud kaks mahukat uuringut ning mõned artiklid.

Eesti keele võõrkeelena professorina on Birute Klaas-Lang tegelenud õppemetoodiliste küsimustega, koostanud õppematerjale ja õpikuid ning käsitlenud eesti keele (võõrkeelena) õpetamise ajalugu. Niisama mitmekihiline nagu Birute Klaas-Langi teadustöö ning ühiskondlik tegevus on olnud ka tema töö õppejõu ning üliõpilastööde juhendajana. Birute Klaas-Lang on Tartu Ülikooli tudengitele õpetanud eesti keele sõnavara ajalugu ja keelekontakte, muu emakeelega tudengitele süntaksiküsimusi, samuti balti keelte ajalugu, kontrastiivset grammatikat ning viinud läbi arvukalt seminare. Viimastel aastatel on enam esil olnud keele ja ühiskonna ning keelepoliitika õppeained. Valdavalt muu emakeelega tudengite üliõpilastööde juhendajana on 
Birute Klaas-Lang tegelenud kõikvõimalike teemadega, mis tudengitele vähegi huvi on pakkunud: grammatikast riigikeele õpetamiseni ning slängi ja vandesõnade kasutamise ja tundmiseni. Ta on juhendanud koodivahetuse, teise keele omandamise ja õppimise teemalisi doktoritöid.

Oma tegevuse eest on Birute pälvinud 2011. aastal Eesti riigilt Valgetähe IV klassi teenetemärgi, teda on autasustatud Prantsusmaa (2007) ja Leedu (2013) riikliku teenetemärgiga. 2003. aastal nimetas Eesti Ettevõtlike Naiste Assotsiatsioon ta aasta naiseks.

Soovime Birutele jätkuvat tegutsemisrõõmu ning jaksu!

Pühendusteose toimetajate ja kolleegide nimel Kristiina Praakli ja Tõnu Tender 